\title{
ANALISIS KINERJA PENGELOLA UPK PERDHAKI KEUSKUPAN KUPANG DALAM UPAYA PENINGKATAN SURVEILENS MALARIA DI PROPINSI NUSA TENGGARA TIMUR
}

\author{
${ }^{1}$ Angela Salome dan ${ }^{2}$ Intje Picauly \\ ${ }^{1}$ UPK PERDHAKI Keuskupan Kupang, Nusa Tenggara Timur \\ ${ }^{2}$ Prodi Ilmu Kesehatan Masyarakat, Fakultas Kesehatan Masyarakat_Undana
}

\begin{abstract}
ABSTRAK
$\mathrm{S}$ istem pencatatan dan pelaporan merupakan bagian dari sistem informasi kesehatan dan merupakan salah satu tugas surveilens adalah indikator keberhasilan suatu kegiatan dalam bidang kesehatan. Tanpa adanya pencatatan dan pelaporan, kegiatan atau program apapun yang dilaksanakan tidak terlihat wujudnya. Output pencatatan dan pelaporan berupa data dan informasi yang berharga dan bernilai, bila digunakan dengan tepat dan benar. Jadi, data dan informasi merupakan unsur terpenting, karena bisa berbicara tentang keberhasilan atau perkembangan sebuah organisasi dan kegiatan. Untuk mencapai dan mengetahui hasil dari kasus malaria, ini tidak terlepas dari sistem pencatatan dan pelaporan yang baik dari penemuan kasus malaria. Kinerja merupakan faktor penting untuk mencapai tujuan. Faktor yang berpengaruh terhadap kinerja:pengetahuan,motivasi,sarana prasarana,dukungan lembaga, pembiayaan.Tujuan penelitian untuk mengetahui pengaruh faktor internal (Pengetahuan, motivasi) dan faktor eksternal (sarana prasarana,dukungan, pembiayaan) terhadap kinerja pengelola pencatatan dan pelaporan malaria di PERDHAKI (Persatuan Karya Dharma Kesehatan Indonesia) Keuskupan Kupang.Jenis penelitian kauntitatif dengan rancangan cross sectional, jumlah sampel 37 pengelola.Metode pengumpulan data menggunakan kuisioner.Analisis data : analisis deskriptif dan regresi linear berganda. Hasil penelitian ada pengaruh motivasi dan dukungan terhadap kinerja.Model persamaan regresi : $\mathrm{y}=$ $10.772+0.919$ (motivasi) +0.127 (dukungan). Kesimpulan Model persamaan regresi : Pengaruh variabel motivasi (x) terhadap kinerja pengelola (y). Motivasi memberikan pengaruh positif terhadap kinerja surveilens pengelola, bahwa setiap peningkatan satu proporsi motivasi akan menaikkan sebesar 0,919 kinerja pengelola ,dukungan lembaga memberikan pengaruh positif terhadap kinerja pengelola,bahwa setiap peningkatan satu proporsi dukungan lembaga akan menaikkan sebesar 0,127 kinerja pengelola.
\end{abstract}

Kata kunci : Faktor, Kinerja,Pengaruh . 


\title{
FACTORS THAT AFFECT ON \\ MALARIA SURVEILLANCE MANAGEMENT PERFORMANCE At The UPK INDONESIAN HEALTH DHARMA WORK ASSOCIATION (PERDHAKI) KEUSKUPAN KUPANG
}

\author{
${ }^{1}$ Angela Salome dan ${ }^{2}$ Intje Picauly \\ ${ }^{1}$ UPK PERDHAKI Keuskupan Kupang, Nusa Tenggara Timur \\ ${ }^{2}$ Prodi Ilmu Kesehatan Masyarakat, Fakultas Kesehatan Masyarakat_Undana
}

\begin{abstract}
$\mathrm{T}$

he recording and reporting system is part of the health information system and one of the surveillance tasks is an indicator of the success of an activity in the health sector. Without recording and reporting, any activities or programs carried out cannot be seen. The output of recording and reporting is in the form of valuable and valuable data and information, if used appropriately and correctly. So, data and information are the most important elements, because they can talk about the success or development of an organization and activities. To achieve and find out the results of malaria cases, this is inseparable from a good recording and reporting system of malaria case findings. Performance from important factor for realize purpose. The factor influential for performance: knowledge, motivation. Infrastructure institute funding support. Research purpose for knowing influence internal factor (knowledge and motivation) and external factor (infrastructure and funding support) about performance manager registration and malaria reporting in PERDHAKI (Association Of Valuantary Health Services of Indonesia) in Diocese of Kupang, kind of research quantitative with program cross sectional, total sample 37 organizer. The aggregate data method use kuisioner. Data analysis: descriptive analysis and linear double regression. Total research motivation influence and support about performance, model regression similarity: $Y=10.772+0.919$ (motivation) +0.127 (support). Conclusion: influence variable motivation $(\mathrm{X})$ for manager performance $(\mathrm{Y})$ motivation give positive influence for performance surveilens manager registration, that every raising one proposition motivation will promote about 0.919 manager performance, institute support give positive influence for manager registration that every raising one proportion institute support will promote about 0.127 manager performance.
\end{abstract}

Keyword : Factor, Performance, Influence. 


\section{PENDAHULUAN}

Kinerja pegawai merupakan salah satu faktor penting demi tercapainya tujuan suatu instansi baik pemerintah maupun swasta. Dalam upaya peningkatan kinerja pegawai, instansi akan memberikan pendidikan, pelatihan dan tunjangan pegawai agar lebih bersungguhsungguh dan selalu semangat dalam melakukan pekerjaannya. PERDHAKI (Persatuan Karya Dharma Kesehatan Indonesia) adalah organisasi profesi yang terpanggil untuk melaksanakan misi keterpihakan pada bidang kemanusiaan, terutama bidang kesehatan yang berperan aktif dalam upaya pemberantasan penyakit malaria di seluruh Indonesia. Dukungan PERDHAKI untuk UPK yang terlibat dalam program Malaria dengan memberikan pelatihan bagi dokter, petugas mikroskop, perawat dan bidan. Dalam pelatihan dibekali pengetahuan dan praktek tentang pencatatan dan pelaporan kasus malaria. Juga mendukung dengan memberikan mikroskop dan RDT kepada UPK yang belum memiliki mikroskop dan RDT untuk melakukan pemeriksaan sediaan darah bagi terduga malaria. Dalam logistik, menyediakan OAM dan Primaquin, atau petugas mikroskopis untuk membantu di UPK yang kesulitan tenaga kesehatan. Memberikan dukungan dana untuk penggantian biaya pengiriman laporan UPK dan transportasi petugas UPK yang mengirimkan laporan. Dalam hal yang lebih teknis, Perdhaki memberikan dukungan kepada UPK untuk Technical Assistance (bimbingan teknis) bagi petugas UPK setiap kali melakukan supervise ke UPK, yang dilakukan dapat berupa pencatatan pelaporan maupun diskusi dan sharing dalam pelaksanaan program.

Fasilitas Pelayanan Kesehatan PERDHAKI sebagai salah satu ujung tombak pelaksanaan program malaria untuk mencapai tujuan nasional. Keterlibatan Fasilitas Pelayanan Kesehatan dalam Program Malaria memberikan kontribusi dalam pemenuhan Standar Pelayanan Minimal (SPM). Dan dengan pelaksanaan pencatatan dan pelaporan yang baik tentang malaria maka akan berdampak positif yaitu laporan setiap bulan. Namun dalam melaksanakan program ini masih ada hambatan yaitu motivasi dari petugas dan petugas UPK yang keterbatasan, yang mengakibatkan beban kerja yang semakin besar karena satu orang petugas dapat merangkap banyak pekerjaan dan berpengaruh terhadap kinerja pencatatan dan pelaporan yang dilakukan setiap bulannya. Ada pula staf di UPK yang telah dilatih namun mengundurkan diri ataupun dipindah ke tempat tugas yang baru maka akan menghambat kinerja pencatatan dan pelaporan di UPK.Keadaan geografis dan letak UPK yang jauh sangat menyulitkan pengiriman laporan tepat waktu. Pengetahuan, ketelitian dan motivasi petugas 
yang belum tahu dengan baik cara mencatat Mal.B maupun cara merekap dari Mal-B1 ke Mal-B2 dan ada petugas UPK yang belum menyadari pentingnya membuat laporan setiap bulan dengan baik. Hal ini berarti bahwa, kinerja pegawai akan tercapai apabila adanya disiplin kerja dari diri sendiri. Disiplin kerja sangat dibutuhkan oleh setiap pegawai atau siapapun yang bekerja. Tata kehidupan berdisiplin akan membuat para pegawai mendapat kemudahan dalam bekerja, dengan begitu akan menciptakan suasana kerja yang kondusif dan mendukung usaha pencapaian tujuan.

Provinsi Nusa Tenggara Timur merupakan provinsi yang memiliki angka API tiga besar di Indonesia, bersama dengan Provinsi Papua Barat dan Papua. NTT merupakan daerah endemis malaria. Kasus malaria pada tahun 2013 tercatat 88.513 atau menyumbang $21 \%$ angka kejadian malaria secara nasional. Pada tahun 2014 sebanyak 72.765 kasus malaria dan pada tahun 2015 sebanyak 36.128 kasus. Di tingkat global, menurut WHO, angka kesakitan dan kematian akibat Malaria juga cenderung menurun pada periode 20052015. Meskipun demikian, masih ada lebih kurang 3,2 milyar jiwa atau hampir separuh penduduk dunia yang berisiko tertular penyakit Malaria. Pada tahun 2015, WHO memperkirakan ada sekitar 214 juta kasus baru malaria dengan kematian sekitar 438 ribu orang di seluruh dunia. Dari seluruh jumlah kematian akibat Malaria di dunia, sekitar sepertiga atau 306 ribu terjadi pada balita.(Berita ini disiarkan oleh Biro Komunikasi dan Pelayanan Masyarakat, Kementerian Kesehatan RI, dipublikasikan pada : sabtu, 30 april 2016.)

Pengendalian dan eliminasi malaria merupakan salah satu program pembangunan kesehatan utama. Eliminasi malaria menjadi salah satu indikator keberhasilan pembangunan program kesehatan dalam Rencana Pembangunan Jangka Menengah Nasional (RPJMN) 2015 - 2019. Selain itu, target pengendalian malaria sebagaimana dituangkan dalam Kepmenkes RI nomor 293/MENKES//SK/IV/2009 tentang Eliminasi Malaria harus tercapai pada tahun 2030.Upaya pengendalian penyakit malaria di Indonesia menunjukkan hasil yang menggembirakan. Hal itu, ditandai dengan penurunan angka Annual Paracit Incident (API) dari sebesar 0,85 \% pada tahun 2014 menjadi sebesar 0,99 \% dibanding tahun 2015. Meskipun begitu, tercatat masih ada beberapa daerah endemis malaria dengan insiden tertinggi yaitu Papua Barat ( API : 31,29\%o), Papua (API : 31,93\%) dan Nusa Tenggara Timur (API : 7,04 \%). Kasus malaria pada tahun 2015 di Provinsi NTT berdasarkan data 
dinas kesehatan provinsi secara umum tinggi walaupun terjadi penurunan jumlah penderita.Data Kabupaten Di NTT API tertinggi di Kabupaten Lembata 69,98 \% dengan jumlah kasus malaria :8.887 kasus dan API terendah di Kabupaten Manggarai : 0,16 \% dengan jumlah kasus :52 kasus.Sedangkan data PERDHAKI kasus malaria terbanyak di RS Lende Moripa (Sumba): 7.175 kasus dan kasus terendah di BP /BKIA St.M.Imakulata Kapan (TTS) :11 kasus. Kasus malaria hampir terdapat di semua kabupaten/kota yang termasuk daerah High Incidence Malaria (API > 5 \%o).

Berdasarkan urian diatas, maka peneliti tertarik untuk mengetahui lebih lanjut pengaruh antar faktor internal (pengetahuan, motivasi) dan faktor eksternal (sarana prasarana, dukungan, pembiayaan) terhadap kinerja surveilens pengelola pencatatan dan pelaporan Malaria di PERDHAKI Keuskupan Agung Kupang. Hal ini disebabkan karena jaringan kerja unit pelayanan kesehatan PERDHAKI sudah tersebar di seluruh Indonesia sebanyak 440 unit. Sementara di_NTT sendiri sudah ada sebanyak 77 Unit pelayanan kesehatan terdiri dari 2 wilayah yaitu 40 Unit pelayanan kesehatan di Wilayah Keuskupan Agung Ende dan terdapat 37 unit kesehatan di wilayah Keuskupan Agung Kupang yang setia melayani kasus malaria.Dan dalam kinerja pegawai tidak terlepas dari kinerja pencatatan dan pelaporan suatu program dalam instansi.

\section{Metode Penelitian}

Desain penelitian yang digunakan dalam penelitian ini adalah Kuantitatif Analitik dengan pendekatan Cross Sectional. Jenis penelitian ini akan menekankan pada waktu pengukuran/observasi data variable independen dan dependen hanya satu kali saja pada suatu saat (point time approach). Hal ini berarti bahwa setiap subyek penelitian hanya diobservasi sekali saja dan pengukuran dilakukan terhadap status karakter atau variabel pada saat pemeriksaan (Sugiyono, 2015). Hal ini dimaksudkan untuk memperoleh gambaran mengenai pengaruh faktor internal (pengetahuan dan motivasi) dan faktor eksternal (sarana,prasarana ,dukungan dan pembiayaan) terhadap kinerja pencatatan dan pelaporan pengelola malaria di UPK Perdhaki Keuskupan Agung Kupang. Sampel dalam penelitian ini adalah total semua populasi yaitu 37 orang pengelola program malaria. Untuk melengkapi penelitian ini peneliti telah mewawancarai informan sebanyak 6 orang, yaitu : 4 orang pimpinan (ketua Perdhaki, Petugas Monev, Bendahara, Petugas logistik) dan 2 orang 
pengelola. Teknik pengambilan sampel dengan kriteria : 1). Semua Surveilens Pengelola program malaria yang telah dilatih; 2). Pengelola dalam keadaan sehat; dan 3). Pengelola bersedia untuk diwawancarai dan mengisi kuisioner. Variabel independen dalam penelitian ini adalah faktor internal (pengetahuan dan motivasi) dan faktor eksternal (sarana dan prasarana,dukungan, pembiayaan) dan variabel dependennya (terikat) adalah Kinerja Surveilens Pengelola pencatatan dan pelaporan malaria. Alat ukur yang digunakan adalah : Observasi,Wawancara, kuiesioner.

Teknik Pengumpulan Data yang digunakan adalah dengan menggunakan kuisioner dan mewawancarai informan sebanyak 6 orang, yaitu : 4 orang pimpinan (ketua Perdhaki, Petugas Monev, Bendahara, petugas logistik) dan 2 orang pengelola. Data yang diperoleh dari kuesioner dianalisis secara univariat untuk memberikan gambaran karakteristik populasi dan penyajian hasil deskriptif melalui frekuensi dan distribusi dari variabel indepen dan variabel dependen dan analisis Bivariat dan Multivariat menggunakan analisis regresi linear sederhana dan berganda dengan tujuan untuk melihat pengaruh sejumlah variabel independen terhadap variabel dependen ( kinerja Pengelola Pencatatan dan pelaporan Program Malaria ).

\section{Hasil Dan Pembahasan}

Pengaruh Faktor Internal (Pengetahuan dan Motivasi) Terhadap Kinerja Surveilens Pengelola Pencatatan dan Pelaporan Malaria

1. Pengaruh Pengetahuan Terhadap Kinerja Surveilens Pengelola

Hasil penelitian diketahui bahwa pengetahuan tidak berpengaruh terhadap kinerja pengelola (sig.0,082>0,05). Hasil ini sejalan dengan pendapat Notoatmodjo (2007) yang menyatakan bahwa pengetahuan merupakan hasil tahu, dan ini terjadi setelah orang melakukan penginderaan terhadap suatu objek tertentu. Sebagian besar pengetahuan manusia diperoleh melalui mata dan telinga. Pengetahuan atau kognitif merupakan domain yang sangat penting untuk terbentuknya tindakan seseorang (Overt Behaviour). Namun, pada tahapan pembentukan perilaku proses pembentukan perilaku tidak selalu didasari oleh pengetahuan. Pengetahuan yang dimaksud dalam penelitian ini adalah pengetahuan responden terhadap Sistem Informasi Kesehatan nasional atau Daerah (SIKNAS /SIKDA). Pengetahuan mengenai pencatatan dan pelaporan malaria setiap hari dan bulan. 
Hasil penelitian ini juga sejalan dengan pembahasan La Pona dalam Walgito (2004) bahwa pengetahuan yang dimiliki tidak selalu menjadi dasar dalam tindakan, sehingga dapat dikatakan pengetahuan yang baik tidak selalu menjadi penyebab seseorang untuk berperilaku baik pula. Ini juga didukung dengan penelitian Efendi (2011) yang mengungkapkan bahwa tidak ada hubungan antara pengetahuan dengan tindakan kinerja petugas. Hal tersebut dapat disebabkan oleh adanya satu petugas yang memiliki pengetahuan yang tinggi tetapi tindakannya kurang atau sebaliknya petugas tersebut memiliki pengetahuan yang rendah namun tindakannya baik. Demikian juga dengan pendapat dari Lorenza ( 2013) bahwa tidak ada hubungan pengetahuan terhadap kinerja, sebab tindakan yang baik berupa melengkapi pencatatan dan melakukan pelaporan, hasil penelitian Meyta yang baik setiap bulan oleh pengelola. Karena hasil dalam penelitian ini menunjukkan bahwa tidak ada pengaruh pengetahuan terhadap kinerja pengelola. Menurut Notoatmodjo (2003) faktor yang memegang peranan di dalam pembentukan perilaku dapat dibedakan menjadi dua yaitu faktor intern dan faktor ekstern. Faktor intern bisa berupa kecerdasan, emosional, jenis kelamin dan belajar. Faktor ekstern meliputi lingkungan.Penelitian yang tidak sejalan dengan penelitian ini adalah menurut hasil penelitian Oliva (2012) menyatakan ada pengaruh faktor pengetahuan terhadap kinerja kerja petugas surveilens karena pengetahuan petugas diukur melalui menjawab kuisioner. Penelitian Ngadarodjatun (2013) bahwa ada hubungan antara pengetahuan petugas dengan kinerja karena pengetahuan merupakan factor awal untuk memahami dan menganalisis suatu fakta.

2. Pengaruh Motivasi Terhadap Kinerja Surveilens Pengelola.

Swanburg (2000) menyatakan bahwa motivasi adalah konsep yang menggambarkan baik kondisi ekstrinsik yang merangsang perilaku tertentu dan respon instrinsik yang menampakkan perilaku manusia. Respon instrinsik ditopang oleh sumber energi yang disebut motif. Sering dijelaskan hal itu sebagai suatu kebutuhan, keinginan atau dorongan, semua manusia hidup mempunyai motivasi. Penelitian ini menemukan bahwa variabel motivasi mempunyai pengaruh terhadap kinerja pengelola pencatatan dan pelaporan UPK Perdhaki Keuskupan Kupang (sig : 0,000>0,05).

Motivasi yang dimaksud dalam penelitian ini adalah keinginan atau dorongan yang berasal dari dalam diri responden meliputi pekerjaan itu sendiri, prestasi, tanggung jawab, 
pengakuan dan pengembangan karir. Hasil penelitian ini sejalan dengan penelitian Nora (2012) yang menunjukkan bahwa adanya hubungan antara motivasi dengan kinerja . Penelitian yang tidak sejalan dengan penelitian ini yaitu : hasil penelitian Oliva Virvizat (2012) menyatakan tidak ada hubungan antara kinerja petugas surveilens dengan motivasi.

Hal ini sesuai dengan yang dikemukakan oleh Notoatmodjo (2007) menyatakan bahawa motivasi merupakan keinginan yang terdapat pada diri seseorang individu yang mendorongnya untuk melakukan perbuatan-perbuatan (perilaku). Maslow dalam Bangsawan (2001) berpendapat bahwa apabila motivasi itu meningkat maka perilaku kerja juga akan meningkat. Sehingga motivasi yang dimiliki oleh seorang pengelola akan menentukan kinerja pengelola tersebut dalam kegiatan pencatatan dan pelaporan. Pada ilmu psikologi, motivasi mengacu pada konsep yang digunakan untuk menerangkan kekuatan-kekuatan yang ada dan bekerja pada diri organisme atau individu yang menjadi penggerak dan pengaruh tingkah laku tersebut. Selain untuk menerangkan kekuatan-kekuatan yang menjadi penggerak dan pengaruh tingkah laku, konsep motivasi juga digunakan untuk menerangkan perbedaan intensitas tingkah laku (Koeswara, 1995). Hasil analisis yang mununjukkan bahwa terdapat pengaruh motivasi terhadap kinerja surveilens pengelola .

Pengaruh Faktor Eksternal (Sarana Prasarana,Dukungan Lembaga dan Pembiayaan) Terhadap Kinerja Surveilens Pengelola.

\section{Pengaruh Sarana prasarana Terhadap Kinerja Surveilens Pengelola.}

Penelitian ini menemukan bahwa variabel sarana prasarana tidak mempunyai pengaruh terhadap kinerja pengelola pencatatan dan pelaporan di UPK Perdhaki Keuskupan Agung Kupang (sig : 0,484 > 0,05). Hasil penelitian ini sejalan dengan hasil Penelitian Heslinda (2004) yang menyatakan bahwa peralatan kerja tidak mempunyai pengaruh terhadap kinerja dan didukung juga oleh hasil penelitian Suganda (2007) yang menyatakan bahwa fasilitas yang tidak tersedia. Sedangkan Eni Haiyanti (2006) menemukan bahwa tidak ada pengaruh terhadap kinerjanya dan menyatakan juga bahwa ketersediaan sarana tidak berpengaruh terhadap kinerja petugas. Semakin lengkap ketersediaan sarana maka akan mempermudah dalam menangani kasus malaria. Kenyataan bahwa para pengelola di UPK PERDHAKI dapat bekerja dengan tepat guna hanya dengan memaksimalkan peralatan yang ada seperti masih banyak peralatan secara manual tapi bisa melaksanakan pelayanan operasional setiap 
hari terutama didaerah terpencil.Sedangkan menurut Oliva (2013) penelitian tidak sejalan dengan penelitian ini yang menyatakan bahwa ada hubungan antara ketersediaan sarana dengan kinerja petugas surveilens malaria,karena dengan ketersediaan sarana dapat membantu kelancaran kinerja petugas.

2. Pengaruh Dukungan Lembaga Terhadap Kinerja Surveilens Pengelola.

Hasil penelitian menunjukkan bahwa variabel dukungan lembaga berpengaruh terhadap kinerja surveilens pengelola pencatatan dan pelaporan di UPK Perdhaki Keuskupan Agung Kupang (sig yaitu : 0,046>0,05). Hal ini berarti semakin baik dukungan lembaga terhadap kinerja pengelola maka akan semakin baik kinerja dari pengelola itu sendiri. Pierce (dalam Kail and Cavanaug, 2000) mendefinisikan dukungan sebagai sumber emosional, informasional atau pendampingan yang diberikan oleh orang- orang disekitar individu untuk menghadapi setiap permasalahan dan krisis yang terjadi sehari- hari dalam kehidupan. Sarafino (2006) menyatakan bahwa dukungan mengacu pada memberikan kenyamanan pada orang lain, merawatnya atau menghargainya. Penelitian yang tidak sejalan dengan penelitian ini menurut hasil penelitian Oliva (2013) dukungan oleh kepala atau lembaga tidak ada hubungan dengan kinerja, sudah ada kesadaran dari petugas untuk melakukan tugasnya sendiri.Menurut S.Notoadmojo : Bentuk dukungan ini dapat berupa infomasi, tingkah laku tertentu, ataupun materi yang dapat menjadikan individu yang menerima bantuan merasa disayangi, diperhatikan dan bernilai.Dalam penelitian ini pengaruh dukungan lembaga terhadap kinerja pengelola pencatatan dan pelaporan malaria.Dukungan yang tinggi dari lembaga PERDHAKI sehingga kinerja pengelola bisa berjalan dengan baik.

\section{Pengaruh Pembiayaan Terhadap Kinerja Surveilens Pengelola.}

Berdasarkan hasil penelitian pada variabel pembiayaan mempunyai sig yaitu : 0,381 > 0,05 sehingga tidak berpengaruh secara parsial terhadap kinerja surveilens pengelola pencatatan dan pelaporan di UPK Perdhaki Keuskupan Agung Kupang,hal ini tidak sesuai dengan penelitian yang dilakukan oleh Ribeiro (2015) yaitu biaya berpengaruh sangat signifkan terhadap

\section{Simpulan}

Berdasarkan hasil penelitian dan pembahasan,maka dapat disimpulkan sebagai berikut: 
1) Tidak ada pengaruh pengetahuan terhadap kinerja surveilens pengelola pencatatan dan laporan di UPK Perdhaki Keuskupan Agung Kupang.

2) Motivasi berpengaruh positif dan signifikan terhadap kinerja survelens pengelola pencatatan dan pelaporan di UPK Perdhaki Keuskupan Agung Kupang.

3) Tidak ada pengaruh sarana prasarana terhadap kinerja pengelola pencatatan dan pelaporan di UPK Perdhaki Keuskupan Agung Kupang.

4) Dukungan lembaga berpengaruh positif dan signifikan terhadap kinerja surveilens pengelola pencatatan dan pelaporan di UPK Perdhaki Keuskupan Agung Kupang.

5) Tidak ada pengaruh pembiayaan terhadap kinerja surveilens pengelola pencatatan dan pelaporan di UPK Perdhaki Keuskupan Agung Kupang.

6) Setiap peningkatan satu proporsi motivasi akan menaikkan sebesar 1 kali kinerja karyawan dalam penelitian ini adalah pengelola.Dukungan lembaga memberikan pengaruh positif terhadap kinerja pengelola,bahwa setiap peningkatan satu proporsi dukungan lembaga akan menaikkan sebesar 0,127 kinerja karyawan dalam penelitian ini adalah pengelola.

\section{Daftar Pustaka}

Efendi Uchjana Onong, 2011. Ilmu Komunikasi Teori dan Praktek. PT. Remaja Rosdakarya, Bandung

Heslinda, 2014. Hubungan Pengetahuan dan Sikap Ibu Post Partum Dengan Pemberian Kolostrum Pada Bayi Baru Lahir Di RSUD Tenriawaru Kabupaten Bone Tahun 2014. Stikes MRM. Makasar

Kepmenkes RI nomor 293/MENKES//SK/IV/2009 : Kepmenkes RI nomor 293/MENKES//SK/IV/2009. Jakarta

Notoatmodjo Soekidjo 2007. Promosi. Kesehatan. Ilmu Perilaku. Penerbit. RINEKA CIPTA. Jakarta

Notoatmodjo Soekidjo 2003. Pengembangan Sumber Daya Manusia, Jakarta: PT. Rineka Cipta. Page 2.

Notoatmodjo Soekidjo 2007. Perilaku Masyarakat. Jakarta: rineka cipta.

Ngadarodjatun, A. Razak, Siti Haerani, 2013. Determinan Kinerja Petugas Imunisasi Di Puskesmas Kabupaten Sigi Provinsi Sulawesi Tengah. SemanticScholar, Published 2013; Jurnal AKK, Vol 2 No 2, Mei 2013, hal 42-47

Oliva Virvizat, 2012. Faktor-Faktor Yang Berhubungan Dengan Kinerja Petugas Surveilans Epidemiologi Penyakit Malaria Tingkat Puskesmas Di Kabupaten Kebumen Tahun 
2012. Unnes Journal of Public Health Vol 2 No 4 (2013): Unnes Journal of Public Health

Sugiyono, 2015. Metode Penelitian Pendidikan Pendekatan Kuantitatif, Kualitatif, dan R \& D. CV Alfabeta. Bandung

Suganda, 2007. Jendela Bandung: Pengalaman Bersama Kompas. Bandung: Penerbit Buku Kompas.

Sarafino, 2006. Health Psychology : Biopsychosocial Interactions. Fifth Edition. USA: John Wiley \& Sons.

Swanburg 2000. Pengantar Kepemimpinan dan Manajemen Keperawatan., Jakarta;EGC 